\title{
The Effect of the Arab Spring Revolution on the Malaysian Hospitality Industry
}

\author{
Ahmad Rasmi Suleiman AlBattat ${ }^{1}$, Ahmad Puad Mat Som ${ }^{1,2}$, Zahed Ghaderi ${ }^{1}$ \& Ala a Nimer AbuKhalifeh ${ }^{1}$ \\ ${ }^{1}$ School of Housing, Building and Planning, Universiti Sains Malaysia, Malaysia \\ ${ }^{2}$ Sustainable Tourism Research Cluster (STRC), Universiti Sains Malaysia, Malaysia \\ Correspondence: Ahmad Rasmi Suleiman AlBattat, School of Housing, Building and Planning, Universiti Sains \\ Malaysia, Penang, Malaysia. Tel: 60-19-595-4499.E-mail: battat_ahmed@yahoo.com
}

Received: December 28, 2012

Accepted: March 19, 2013

Online Published: April 17, 2013

doi:10.5539/ibr.v6n5p92

URL: http://dx.doi.org/10.5539/ibr.v6n5p92

\begin{abstract}
The current paper investigates the effects of the Arab revolution crisis on the Malaysian hotel and tourism industry. This crisis started in Tunis after decades of bureaucratic spontaneous protests and demonstrations which later spread to Egypt, Yemen, Bahrain, Libya and Syria. There was a wave of inversions experienced in the last two years shifting the balance of power in the Middle East and North Africa. This research aims to mark one of the first attempts to investigate the effect of this crisis on the hotel and tourism sector in Malaysia. It will then discuss its effects on the tourist arrivals from the Middle East to Malaysia and analyze the occupancy rate during the Arab spring revolution. The results of this study explain that, during the crisis, statistics show that international arrivals to Malaysia from the Middle East and the world is on the increase. This is especially true of the countries currently in a revolution with regard to their country's insecurity and their search for alternative safe destinations.
\end{abstract}

Keywords: Arab revolution, crisis, hotel, tourism, Malaysia

\section{Introduction}

A crisis is an unforeseen incident which creates instability and confusion and is a threat to the criterion of a society (Coyne, 2011). "It seems to sum up a mix of a self-correction mechanisms that brought the global output back to its original logistic growth pattern" (Devezas, 2010, p. 739). Many scholars have done a considerable number of studies that have focused on the crisis from their specific viewpoint (Hall 2010). Allen et al. (2012) studied the structure of financial systems and financial crises. It was suggested that governments should emphasize on a balanced financial system structure to help the country recover from a financial crisis. This originated in the United States, seen as a mortgage problem, and has expanded to Asia affecting the economy and the financial situation (Hong et al., 2010). The result is a monetary decline between expenses obligations and vast sums of national capital (O’Brien, 2012).

Arnold (2012); Goh et al., (2005) explained that the accumulation effect of the international political economy was due to the powers in the financial sector. Anwar and Cooray (2012) clarified that a quality of governance can insure the financial development. Amara (2012) focused on the cumulative roles of economics, politics, and the military, all of them will affect the chances of building up security forces. While many studies have investigated the effects of various crises on the tourism and hospitality sector such as, the Bali bombing, September 11 events, Iraq war, SARS (Bor, 2007; Eugenio-Martin et al., 2005; Kim et al., 2005; Law, 2005; Mendoza, 2010; Prideaux et al., 2008; Sperling \& Biermann, 2009; Wen et al., 2005). Some researchers have studied the Arab spring revolution from several points of view. Benmamoun et al. (2012) explored the mechanisms which shaped the political and social structures.

The tourism and hospitality sectors are most liable and vulnerable industries to crises (Henderson, 2007; Korstanje \& Tarlow, 2012; Ritchie, 2009), and were affected by many financial, economic, and political crises. Substantial attention has been cast on the role of such crisis events and typologies on the tourism sector (Blake \& Sinclair, 2003; Hall 2010; Laws \& Prideaux, 2005). Many scholars have concentrated on the crisis affecting the hospitality and tourism sectors and the impacts on these sectors in recent years (Cohen \& Neal, 2010; Hall 2010; Lean \& Smyth, 2009; Lim, 2000). In frequent studies have been done to study the Arab revolution crisis 
attempted to investigate compared to other kind of crises (Hall, 2001; Faulkner, 2001; Anderson, 2006; Prideaux, 1999; Prideaux et al., 2003; Tan et al., 2002; Ghaderi et al., 2012; De Sausmarez, 2004, 2007).

The literature on the Arab spring revolution crises in the hospitality and tourism industry has had few significant developments in the past two years 2011-2012. Reviewing the literature suggests that no or limited studies have explored the effects of Arab Revolution Crisis on the tourism and hospitality businesses, Although few studies were investigated the political circumstances in the region (Becheur, 2011; Benmamoun et al., 2012; Cook \& Stathis, 2012; Johnstone \& Mazo, 2011; Spindel, 2011; Springborg, 2011; Toolan, 2012, p.iv; Tyner \& Rice, 2012).

The purpose of this study is to investigate if the Malaysian hospitality and tourism sectors were affected by the Arab spring revolution due to tourist arrivals from the Middle East. And the fluctuation of tourist arrivals from the Middle East region. First, this paper presents a brief review of the literature regarding the Arab spring revolution. Second, study statistics are outlined followed by the findings of the study. The next section of this study will conduct an extensive review about the Arab spring revolution crisis.

\section{Literature Review}

\subsection{Arab Spring Revolution}

Although the Arab Nations have long been some of the least free; most tend to be war prone and economically underdeveloped regions. However, they have not congested the slow creep of globalization, democracy, modernity and dignity (Wiarda, 2012). Increased education and new technology such as the internet, have made Arab societies increasingly aware of the many plaguing economic and political deficiencies in their countries (Boukhars, 2011; Helfont \& Helfont, 2012). The beginning of the Arab spring revolution dates back to December 2010 in the city of Sidi Bouzid, Tunisia (Grinin \& Korotayev, 2012). The initial incident was during the police seizure of a vegetable cart owned by Mohammed Bouazizi (Aleya-Sghaier, 2012; Hannoum, 2012). A local street vendor self-immolated in front of a Tunisian police headquarters. Media coverage of this incident sparked daily protests in Sidi Bouzid which speedily increased in the capital of Tunis. The objection in Tunis ultimately led Tunisian President Zain al-Abidin Ben Ali to resign from office (Kamrava, 2012). The Tunisian revolt was the first modern Arab revolution to succeed in removing a long serving autocrat that would move towards to defining “Arab Spring” (Schraeder, 2012; Toolan, 2012, p.iv).

From Tunisia, revolutionary enthusiasm extended to Egypt after the decline in wages, increased job uncertainty, towering inequality and the strangling of union activity (Abou-El-Fadl, 2012; Saikal, 2011), a thousand Egyptian protesters camped in "Tahrir Square" in the central of Cairo. They insisted that changes are needed in a government that had failed to deal with a deteriorating economic situation. Eventually, these uprisings forced Hosni Mubarak to withdraw from power. While restricted violence took place early in the uprising, the Egyptian military did not interfere on behalf of the government, tacitly allowing the protests to crop up. Much of the success in overthrowing Hosni Mubarak flowed from the protesters who refused to leave Tahrir Square combined with the Egyptian military`s passive approval of the protests (Toolan, 2012, p.iv).

A new era was flourishing after a free and fair election but the fear from the fiasco of the revolution in Egypt feared to cause long term consequences affecting the economy and the hospitality industry (The Observer, 2012). Based on the success in Egypt, an uprising soon occurred in Yemen and Bahrain. Unlike in Egypt, on the other hand, protesters in those countries were met with a strong military response. Bahrain's inward military support appeared in the form of troops from Saudi Arabia to repress the uprisings. Saudi Arabia supported Bahrain to avoid demonstrations from crossing into Saudi Arabia. (Michael-Matsas, 2011; Toolan, 2012, p.iv; Tyner \& Rice, 2012).

The most aggressive uprising, however, occurred in Libya. Revolutionary groups in the city of Misrata eastern Libya, started an armed struggle against the Gaddafi system. Over the course of nine months, rebel groups backed by NATO air power fought to the Libyan capital. The longest and the most dissimilar revolution thus far has occurred in Syria. The Syrian uprising has not shaped the quick decision that occurred in Egypt (Becheur, 2011; Spindel, 2011; Toolan, 2012, p.iv).

\subsection{Middle East and North Africa (MENA)}

The instability in the Middle East and North Africa will take a decade until stability and full security is achieved. The population explosion mentioned in the figure 1, shows that within the next twenty years the population in the Middle East will have increased around $70 \%$ with the majority of growth in the Arab nations (Cordesman, 2011). 


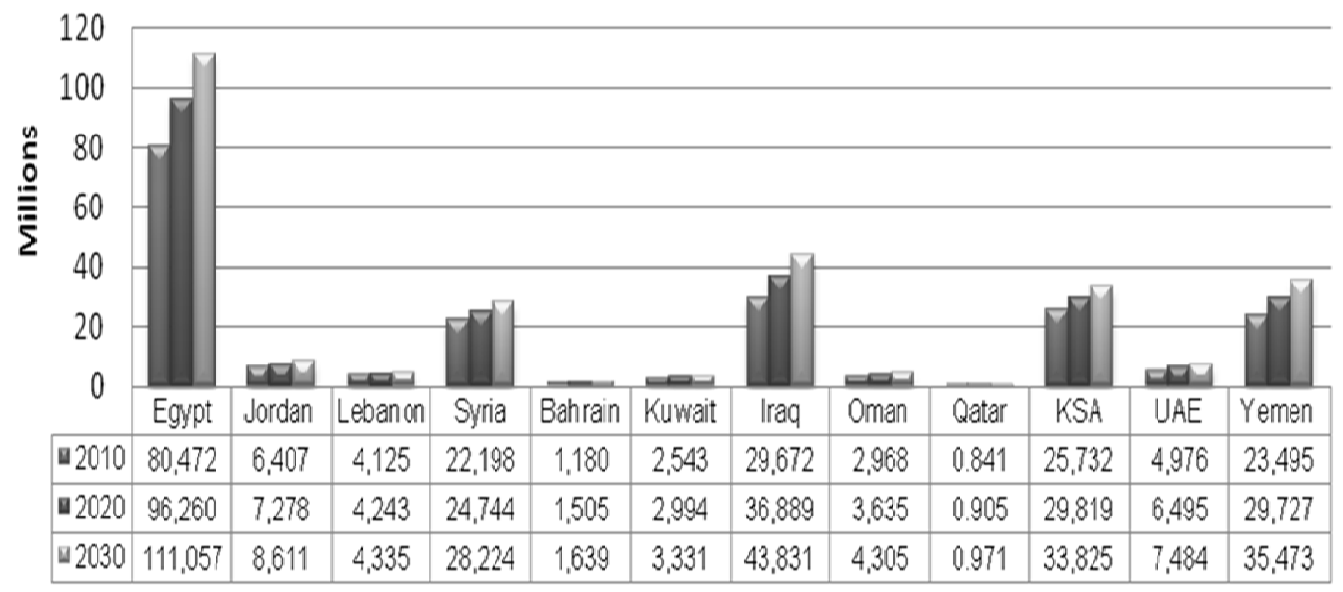

Figure 1. Population explosion in some Arab countries from the Middle East

Source: U.S. Census Bureau: International Database, Cited in Cordesman, 2011.

The increased Per Capita Income for the Arab countries oil production recorded to be the highest. World ranking producers are Qatar $(\$ 38,281)$, Kuwait $(\$ 21,416)$, UAE $(\$ 13,508)$, Saudi Arabia $(\$ 7,685)$, and Libya $(\$ 6,837)$. See table 1 (Cordesman, 2011). Our focus should remain on the facts from the MENA region to attract more tourists to visit Malaysia.

Table 1. Per Capita Income for Arab countries oil producers

\begin{tabular}{lll}
\hline Country & World Ranking & Limits to Oil Wealth (\$ Per Capita in 2010) \\
\hline Qatar & 1 & $\$ 38,281$ \\
Kuwait & 10 & $\$ 21,416$ \\
UAE & 9 & $\$ 13,508$ \\
Saudi Arabia & 55 & $\$ 7,685$ \\
Libya & 52 & $\$ 6,837$ \\
Iraq & 159 & $\$ 1,686$ \\
Algeria & 127 & $\$ 1,540$ \\
\hline
\end{tabular}

Source: CIA World Factbook, Cited in Cordesman, 2011.

\subsection{Tourism and Hospitality Industry in Malaysia}

According to the UNWTO (2012) Malaysia has become one of the top 10 leading tourism destination in arrivals and rates in the top 15 in international receipts. Malaysia's tourism is considered as an essential contributor to its economy (Chon et al., 1997). It is expected that by 2020 the tourism industry will generate RM103.6 billion in GNI with an arrival increasing to 36 million. Malaysia has a strong starting position to boost itself as a key tourism destination. This industry has grown rapidly from $12 \%-14 \%$ annually, and has a sturdy international competitive position which can be used to enhance the sector involvement in the local economy. The International visitor arrivals to Malaysia have but it has yield low income increased in actual arrivals but has a low yield of tourists. For example in 2009, Malaysia received 24 million arrivals; Where $78 \%$ came from neighboring short-haul countries such as Singapure, Vietnam, the Philippines, and Indonesia. $15 \%$ of arrivals came from medium-haul markets such as India, China, UAE, Saudi Arabia, Japan, and Australia, whereas, 7\% came from long-haul markets like the United Kingdom, France, Germany, and Russia (UNWTO, 2012).

\subsection{Tourist Arrivals to Malaysia during the Arab Spring Revolution (2011-2012)}

The tourism and hospitality industry has been an important commerce in Malaysia for several years (Ghaderi et al., 2012; Khalifah \& Tahir, 1997; Musa, 2000). During the Arab revolution in the Middle East, Malaysia was still able to attract 11,632,483 tourist arrivals for the first six months of 2012. This was a registered growth of $2.4 \%$ compared to the $11,362,862$ arrivals for the same period in 2011. Respectively, the total tourist revenue from January to June 2012 increased by $4.0 \%$ generating RM 26.8 billion to the country`s revenue compared to RM 25.7 billion in 2011 (Tourism Malaysia, 2012b). Table 2 shows the international arrivals from the Arab countries to Malaysia. 
Table 2. International arrivals from Arab countries to Malaysia

\begin{tabular}{llll}
\hline \multirow{2}{*}{ Country of Nationality } & \multicolumn{2}{l}{ January - June } & Growth\% \\
\cline { 2 - 4 } & 2011 & 2012 & 71.7 \\
\hline Saudi Arabia & 31.900 & 54,761 & 33.2 \\
Oman & 10,904 & 14,522 & 17.4 \\
Kuwait & 9,224 & 10,826 & $(14.3)$ \\
UAE & 9,488 & 8,128 & 56.4 \\
Iraq & 5,134 & 8,029 & 38.0 \\
Yemen & 5,679 & 7,839 & 24.2 \\
Egypt & 6,153 & 7,642 & 70.2 \\
Grand Total & 78,482 & 111,747 & \\
\hline
\end{tabular}

Source: Tourism Malaysia, 2012b.

An Arab market with a noteably remarkable growth is Saudi Arabia with a growth rate of (71.7\%). The increase in arrivals was due to the Arab Saudi new immigration rule which now requires all outgoing tourists to own individual passports. Prior to this ruling, children travelled on their parent's passports. Two periods of long holidays - January to March and June to July - (Arab Season) also contributed to the increase in Saudi Arabian travelers. Other Arab countries have shown a high growth rate: Oman (33.2\%), Kuwait (17.4\%), Iraq (56.4\%), Yemen (38.0\%), and Egypt (42.2\%) (Tourism Malaysia, 2012c).

The second table includes an average occupancy rate by locality 2010/2011 for international tourist arrivals with a specific locational focus on Malaysia. Kuala Lumpur is ranked the highest occupancy rate at (68.6\%) for 2011, compared to $(66.9 \%)$ in 2010 with a variance of $(1.7 \%)$. Whereas, Putrajaya has decreased (-1.8\%) to $(65.8 \%)$ in 2011 from (67.5\%) in 2010 during the Arab spring revolution (Tourism Malaysia, 2012a). Table 3 shows the Average Occupancy Rate (AOR) of hotels by locality for 2010/2011.

Table 3. The average occupancy rate (AOR) of hotels by locality 2010/2011

\begin{tabular}{llll}
\hline Locality & 2010 & 2011 & Variance \\
\hline Kuala Lumpur F.T. & 66.9 & 68.6 & 1.7 \\
Putrajaya F.T. & 67.5 & 65.8 & -1.8 \\
Selangor & 62.7 & 66.2 & 3.4 \\
Perak & 47.5 & 47.2 & -0.3 \\
Penang & 60.2 & 63.5 & 3.3 \\
Kedah & 49.6 & 51.5 & 1.9 \\
Perlis & 40.9 & 37.1 & -3.8 \\
Kelantan & 51.8 & 39.0 & -12.8 \\
Terengganu & 42.8 & 42.5 & -0.3 \\
Pahang & 76.6 & 79.1 & 2.5 \\
Johor & 54.5 & 52.0 & -2.4 \\
Melaka & 59.1 & 60.8 & 1.7 \\
Negeri Sembilan & 37.0 & 40.6 & 3.5 \\
Sabah & 56.2 & 58.8 & 2.6 \\
Labuan F.T. & 75.3 & 65.6 & -9.7 \\
Sarawak & 54.4 & 53.3 & -1.1 \\
Malaysia & 59.3 & 60.6 & 1.3 \\
\hline
\end{tabular}

Source: Tourism Malaysia, 2012a.

\section{Findings and Discussions}

In this sense, Malaysia has offered bounds of attractions to satisfy tourist needs, wants, and expectations, with a good reputation as a safe country. Malaysia is also, qualified with local and international human resources working with an abundance of classified hotels. This aids to be a fertile ground for Malaysia to stay at the top for tourism attractions and the ability to compete other neighboring destinations in Southeast Asia (NKEA, 2010). Malaysia is also able to attract tourists from the Middle East and from around the world who have been forced to change their tourist destinations due to the Arab spring revolution. These findings fall in line with (Hanafiah \& Harun, 2010). 
It is important to focus on the Islamic parties who led the Arab countries after the revolution (Bagherpour, 2012; Soguk, 2011). From these solid facts and real statistics, Malaysia could benefit much from the crisis. First, tourists will start to search about for safe attractive destinations with competitive services. Second, the population inflation in the Middle East countries could generate a current and future tourism to Malaysia. Third, the increase of wealth per capita will bring elite big spenders which will enhance the hotel and tourism receipts (NKEA, 2010).

Finally, religious tourism could be used (Zamani-Farahani \& Musa, 2012) to reveal Malaysia as an Islamic country with regard to Islamic culture (Henderson, 2003) as an attraction for Islamic nations from the Middle East. Malaysia is also considered desirable for its traditional enrichment and food. Therefore, tourism and hospitality stakeholders should take action to attract more tourists from these countries to come to Malaysia.

\section{Conclusion}

This study tried to investigate the effects of the Arab spring revolution on the Malaysian hotel and tourism industry. The revolution started at the end of 2010 and during 2011-2012. The study results showed that the crisis in the Middle-East created opportunities for Malaysia to attract more tourists from the aforementioned region. Malaysia is said to be a fantastic and favor tourist destination for Arab people to visit. The reason could be due to its Islamic culture and visa facilitation which enables Arab to come and stay in Malaysia. With regard to current literature, the review in this study has found a small number of researchers who have previously focused on the effects of the Arab revolution on the hotel and tourism industry in Malaysia. This is deemed part of the overall analysis. An in depth look into the statistics of tourist arrivals from Arab and other countries, with previous crises situation to Malaysia is also considered. Finally, the findings showed that Malaysia's tourism was positively affected by the increased number of international and Arab tourist arrivals throughout the Arab spring revolution. The reason was found to be that the international and Arab tourists began searching for new and safe countries. As this paper is only conceptual, future studies may incorporate empirical data that will be collected from Arab tourists and selected hotels in Malaysia.

\section{Acknowledgments}

The authors would like to extend their appreciation to the Universiti Sains Malaysia for the Research University Grant under the Sustainable Tourism Research Cluster entitled 'Tourism Planning' [Grant No. 1001/PTS/8660013] which made this study and paper possible. The authors are also grateful for the kind assistance and the constructive suggestions of the anonymous reviewers which helped strengthen this paper.

\section{References}

Abou-El-Fadl, R. (2012). Beyond Conventional Transitional Justice: Egypt's 2011 Revolution and the Absence of Political Will. International Journal of Transitional Justice, 6(2), 318-330. http://dx.doi.org/10.1093/ijtj/ijs011

Aleya-Sghaier, A. (2012). The Tunisian Revolution: The Revolution of Dignity. The Journal of the Middle East and Africa, 3(1), 18-45. http://dx.doi.org/10.1080/21520844.2012.675545

Allen, F., Gu, X., \& Kowalewski, O. (2012). Financial crisis, structure and reform. Journal of Banking \&amp; Finance, 36(11), 2960-2973. http://dx.doi.org/10.1016/j.jbankfin.2012.06.002

Amara, J. (2012). Implications of military stabilization efforts on economic development and security: The case of Iraq. Journal of Development Economics, 99(2), 244-254. http://dx.doi.org/10.1016/j.jdeveco.2012.02.001

Anderson, B. A. (2006). Crisis management in the Australian tourism industry: Preparedness, personnel and postscript. Tourism Management, 27(6), 1290-1297. http://dx.doi.org/10.1016/j.tourman.2005.06.007

Anwar, S., \& Cooray, A. (2012). Financial development, political rights, civil liberties and economic growth: $\begin{array}{lllll}\text { Evidence from } \quad \text { South Asia. Economic Modelling, 29(3), } & \text { 974-981. }\end{array}$ http://dx.doi.org/10.1016/j.econmod.2012.02.009

Arnold, P. J. (2012). The political economy of financial harmonization: The East Asian financial crisis and the rise of international accounting standards. Accounting, Organizations and Society, 37(6), 361-381. http://dx.doi.org/10.1016/j.aos.2012.05.001

Bagherpour, A. (2012). Religion and the evolution of democracy: A revised selectorate model for the arab spring. (PhD Dissertation). The Claremont Graduate University, USA. Retrieved from http://search.proquest.com/docview/1024141800?accountid=14645 
Becheur, M. (2011). The Jasmine Revolution and the Tourism Industry in Tunisia. (Master Dissertation). University of Nevada, Las Vegas. Retrieved from http://digitalscholarship.unlv.edu/thesesdissertations/1141

Benmamoun, M., Kalliny, M., \& Cropf, R. A. (2012). The Arab Spring, MNEs, and virtual public spheres. Multinational Business Review, 20(1), 26-43. http://dx.doi.org/10.1108/15253831211217189

Blake, A., \& Sinclair, M. T. (2003). Tourism Crisis Management: US Response to September 11. Annals of Tourism Research, 30(4), 813-832. http://dx.doi.org/10.1016/S0160-7383(03)00056-2

Bor, J. (2007). The political economy of AIDS leadership in developing countries: An exploratory analysis. Social Science \&amp; Medicine, 64(8), 1585-1599. http://dx.doi.org/10.1016/j.socscimed.2006.12.005

Boukhars, A. (2011). The Arab Revolutions for Dignity. American Foreign Policy Interests, 33(2), 61-68. http://dx.doi.org/10.1080/10803920.2011.570734

Chon, K. S., Elgin, B., \& Oppermann, M. (1997). Malaysia's Tourism Development and Marketing. Journal of $\begin{array}{lllll}\text { International Hospitality, Leisure \& Tourism Management, } & 1(1), & \text { 79-89. }\end{array}$ http://dx.doi.org/10.1300/J268v01n01_06

CIA World Factbook. (Cited in Cordesman, 2011). For per capita income ranking, DOE/EIA, for per capita oil export revenues. Retrieved from http://www.eia.gov/countries/regions-topics.cfm?fips=OPEC

Cohen, E., \& Neal, M. (2010). Coinciding crises and tourism in contemporary Thailand. Current Issues in Tourism, 13(5), 455-475. http://dx.doi.org/10.1080/13683500.2010.491898

Cook, B. J., \& Stathis, M. (2012). Democracy and Islam: promises and perils for the Arab Spring protests. Journal of Global Responsibility, 3(2), 175-186. http://dx.doi.org/10.1108/20412561211260485

Cordesman, A. (2011). Rethinking the Arab "Spring": Stability and Security in Egypt, Libya, Tunisia, and the Rest of the MENA Region (pp. 1-13). Washington, USA: Center for Stratigic \& International Studies.

Coyne, C. J. (2011). Constitutions and crisis. Journal of Economic Behavior \&amp; Organization, 80(2), 351-357. http://dx.doi.org/10.1016/j.jebo.2011.05.011

De Sausmarez, N. (2004). Malaysia's Response to the Asian Financial Crisis. Journal of Travel \& Tourism Marketing, 15(4), 217-231. http://dx.doi.org/10.1300/J073v15n04_01

De Sausmarez, N. (2007). The Potential for Tourism in Post-crisis Recovery: Lessons from Malaysia's Experience of the Asian Financial Crisis. Asia Pacific Business Review, 13(2), 277-299. http://dx.doi.org/10.1080/13602380601045587

Devezas, T. (2010). Crises, depressions, and expansions: Global analysis and secular trends. Technological Forecasting and Social Change, 77(5), 739-761. http://dx.doi.org/10.1016/j.techfore.2010.04.010

Eugenio-Martin, J. L., Sinclair, M. T., \& Yeoman, I. (2005). Quantifying the Effects of Tourism Crises: An Application to Scotland. Journal of Travel \& Tourism Marketing, 19(2-3), 21-34. http://dx.doi.org/10.1300/J073v19n02_03

Faulkner, B. (2001). Towards a framework for tourism disaster management. Tourism Management, 22(2), 135-147. http://dx.doi.org/10.1016/S0261-5177(00)00048-0

Ghaderi, Z., \& Mat Som, A. P. (2012). Impact of global economic crisis on tourism business in penang. South Asian Journal of Tourism and Heritage, 5(1), 40-46.

Ghaderi, Z., Mat Som, A. P., \& Henderson, J. C. (2012). Tourism crises and island destinations: Experiences in $\begin{array}{lllll}\text { Penang, } & \text { Malaysia. Tourism }\end{array}$ http://dx.doi.org/10.1016/j.tmp.2012.03.006

Goh, C. C., Kang, S. J., \& Sawada, Y. A. (2005). How did Korean households cope with negative shocks from the financial crisis? Journal of Asian Economics, 16(2), 239-254. http://dx.doi.org/10.1016/j.asieco.2005.01.006

Grinin, L., \& Korotayev, A. (2012). Does “Arab Spring” Mean The Beginning Of World System Reconfiguration? World Futures, 68(7), 471-505.

Hall, C. (2010). Crisis events in Tourism: subjects of crisis in tourism. Current issues in Tourism, 13(5), 401-417. http://dx.doi.org/10.1016/j.tmp.2012.03.006

Hall, C. M. (2001). Chapter 2 - Tourism and Political Relationships in Southeast Asia. In T. Peggy, T. C. Chang, T. C. C. K. C. HoA2 - Peggy Teo \& K. C. Ho (Eds.), Interconnected Worlds (pp. 13-26). Amsterdam: 
Pergamon.

Hanafiah, M., \& Harun, M. (2010). Tourism Demand in Malaysia: A cross-sectional pool time-series analysis. International Journal of Trade, Economics and Finance, 1(1), 80-83.

Hannoum, A. (2012). Tangier in the time of Arab revolutions: an ethnopolitical diary. The Journal of North African Studies, 1-19.

Helfont, S., \& Helfont, T. (2012). Jordan: Between the Arab Spring and the Gulf Cooperation Council. Orbis, 56(1), 82-95. http://dx.doi.org/10.1016/j.orbis.2011.10.005

Henderson, J. (2003). Managing Tourism and Islam in Peninsular Malaysia. Tourism Management, 24(4), 447-456. http://dx.doi.org/10.1016/S0261-5177(02)00106-1

Henderson, J. (2007). Managing Tourism Crises: Causes, Consequences and Management (The Management of Hospitality and Tourism Enterprises). Oxford: Butterworth-Heinemann.

Hong, K., Lee, J. W., \& Tang, H. C. (2010). Crises in Asia: Historical perspectives and implications. Journal of Asian Economics, 21(3), 265-279. http://dx.doi.org/10.1016/j.asieco.2009.07.006

Johnstone, S., \& Mazo, J. (2011). Global Warming and the Arab Spring. Survival: Global Politics and Strategy, 53(2), 11-17.

Kamrava, M. (2012). The Arab Spring and the Saudi-Led Counterrevolution. Orbis, 56(1), 96-104. http://dx.doi.org/10.1016/j.orbis.2011.10.011

Khalifah, Z., \& Tahir, S. (1997). Malaysia: Tourism in perspective. In F. Go, \& C. L. Jenkins (Eds.), Tourism and economic development in Asia and Australasia. London: Cassel.

Kim, S. S., Chun, H., \& Lee, H. (2005). The effects of SARS on the Korean hotel industry and measures to overcome the crisis: A case study of six Korean five-star hotels. Asia Pacific Journal of Tourism Research, 10(4), 369-377. http://dx.doi.org/10.1080/10941660500363694

Korstanje, M. E., \& Tarlow, P. (2012). Being lost: tourism, risk and vulnerability in the post-'9/11' entertainment industry. Journal of Tourism and Cultural Change, 10(1), 22-33. http://dx.doi.org/10.1080/14766825.2011.639455

Law, R. (2005). A Perspective on SARS and Education in Hospitality and Tourism. Journal of Teaching in Travel \& Tourism, 5(4), 53-59. http://dx.doi.org/10.1300/J172v05n04 04

Laws, E., \& Prideaux, B. (2005). Crisis Management: A Suggested Typology. Journal of Travel \& Tourism Marketing, 19(2-3), 1-8. http://dx.doi.org/10.1300/J073v19n02_01

Lean, H. H., \& Smyth, R. (2009). Asian Financial Crisis, Avian Flu and Terrorist Threats: Are Shocks to Malaysian Tourist Arrivals Permanent or Transitory? Asia Pacific Journal of Tourism Research, 14(3), 301-321. http://dx.doi.org/10.1080/10941660903024034

Lim, J. Y. (2000). The Effects of the East Asian Crisis on the Employment of Women and Men: The Philippine Case. World Development, 28(7), 1285-1306. http://dx.doi.org/10.1016/S0305-750X(00)00023-1

Mendoza, R. U. (2010). Was the Asian crisis a wake-up call?: Foreign reserves as self-protection. Journal of Asian Economics, 21(1), 1-19. http://dx.doi.org/10.1016/j.asieco.2009.05.003

Michael-Matsas, S. (2011). The Arab Spring: The Revolution at the Doors of Europe. Critique, 39(3), $421-432$. http://dx.doi.org/10.1080/03017605.2011.583094

Musa, G. (2000). Tourism in Malaysia. In C. M. Hall, \& S. Page (Eds.), Tourism in South and Southeast Asia: Issues and cases (pp. 144-156).

NKEA. (2010). Economic Transformation Programme A Roadmap For Malaysia, Revving Up the Tourism Industry (10th ed., pp. 317-353). Malaysia: Performance Management \& Delivery Unit (Pemandu).

O’Brien, A. (2012). Wasting a good crisis: Developmental Failure and Irish Tourism Since 2008. Annals of Tourism Research, 39(2), 1138-1155. http://dx.doi.org/10.1016/j.annals.2011.12.008

Prideaux, B. (1999). Tourism Perspectives of the Asian Financial Crisis: Lessons for the Future. Current issues in Tourism, 2(4), 279-293. http://dx.doi.org/10.1080/13683509908667856

Prideaux, B., Coghlan, A., \& Falco-Mammone, F. (2008). Post Crisis Recovery. Journal of Travel \& Tourism Marketing, 23(2-4), 163-174. http://dx.doi.org/10.1300/J073v23n02_13

Prideaux, B., Laws, E., \& Faulkner, B. (2003). Events in Indonesia: exploring the limits to formal tourism trends 
forecasting methods in complex crisis situations. Tourism Management, 24(4), 475-487. http://dx.doi.org/10.1016/S0261-5177(02)00115-2

Ritchie, B. W. (2009). Tourism crises: management responses and theoretical insight. Current Issues in Tourism, 12(4), 405-408. http://dx.doi.org/10.1080/13683500802420519

Saikal, A. (2011). Authoritarianism, revolution and democracy: Egypt and beyond. Australian Journal of International Affairs, 65(5), 530-544. http://dx.doi.org/10.1080/10357718.2011.613903

Schraeder, P. J. (2012). Tunisia's Jasmine Revolution \&amp; the Arab Spring: Implications for International Intervention. Orbis, 56(4), 662-675. http://dx.doi.org/10.1016/j.orbis.2012.08.009

Scott, N., \& Laws, E. (2005). Tourism Crises and Disasters: Enhancing Understanding of System Effects. Journal of Travel \& Tourism Marketing, 19(2-3), 149-158. http://dx.doi.org/10.1300/J073v19n02_12

Soguk, N. (2011). Uprisings in 'Arab Streets', Revolutions in 'Arab Minds'! A Provocation. Globalizations, 8(5), 595-599. http://dx.doi.org/10.1080/14747731.2011.621280

Sperling, W., \& Biermann, T. (2009). Influenza H1N1 and the world wide economic crisis - A model of coherence? Medical Hypotheses, 73(5), 664-666. http://dx.doi.org/10.1016/j.mehy.2009.05.011

Spindel, C. (2011). The People Want to Topple the Regime: Exploring the Arab Spring in Egypt, Syria, and Jordan. SAGE Open, 1-11.

Springborg, R. (2011). The Precarious Economics of Arab Spring Survival. Global Politics and Strategy, 53(6), $85-104$.

Tan, A. Y. F., McCahon, C., \& Miller, J. (2002). Modeling Tourist Flows to Indonesia and Malaysia. Journal of Travel \& Tourism Marketing, 13(1-2), 61-82. http://dx.doi.org/10.1300/J073v13n01_05

The Observer. (2012). Leading article: ARAB SPRING: Egypt's democratic revolution is being crushed by a $\begin{array}{lllll}\text { slow-motion } & \text { coup. } & \text { p. } & 28 . & \text { Retrieved }\end{array}$ http://search.proquest.com/docview/1021916351?accountid=14645

Toolan, B. P. (2012). Korean Spring? An Analysis of the Arab Spring and Its Relevance for North Korea. (Master Dissertation). Virginia Military Institute, Lexington, Virginia, 1998, Virginia.

Tourism Malaysia. (2012a). Average Occupancy Rates (AOR) Of Hotels by Locality 2010/2011. Retrieved 19 September 2012

from http://corporate.tourism.gov.my/images/research/pdf/2011/AOR/AOR_2010_2011.pdf

Tourism Malaysia. (2012b). Malaysia Tourist Arrivals by Country of Nationality. Retrieved 19 September 2012 from http://corporate.tourism.gov.my/images/research/pdf/2012/Tourist_Arrivals_June_2012.pdf

Tourism Malaysia. (2012c). Tourist Arrivals to Malaysia Continue to Increase. Retrieved 18 September 2012 from http://corporate.tourism.gov.my/mediacentre.asp?page=news_desk\&news_id=713

Tyner, J. A., \& Rice, S. (2012). Moving beyond the 'Arab Spring': The ethnic, temporal, and spatial bounding of a political movement. Political Geography, 31, 131-132. http://dx.doi.org/10.1016/j.polgeo.2012.01.001

U.S. Census Bureau: International Database. (Cited in Cordesman, 2011). Retrieved from http://www.census.gov/ipc/www/idb/informationGateway.php

UNWTO. (2012). Tourism Highlights. UNWTO: Madrid, Spain.

Wen, Z., Huimin, G., \& Kavanaugh, R. R. (2005). The Impacts of SARS on the Consumer Behaviour of Chinese Domestic Tourists. Current Issues in Tourism, 8(1), 22-38. http://dx.doi.org/10.1080/13683500508668203

Wiarda, H. J. (2012). Arab Fall or Arab Winter? American Foreign Policy Interests, 34(3), 134-137.

Zamani-Farahani, H., \& Musa, G. (2012). The relationship between Islamic religiosity and residents' perceptions of socio-cultural impacts of tourism in Iran: Case studies of Sare'in and Masooleh. Tourism Management, 33(4), 802-814. http://dx.doi.org/10.1016/j.tourman.2011.09.003 